\title{
PEMANFAATAN MEDIA PEMBELAJARAN MATEMATIKA BERBASIS TEKNOLOGI: PERSEPSI SISWA SMA
}

\author{
Ulfa Lu'luilmaknun ${ }^{1}$, NilzaHumaira Salsabila ${ }^{2}$ Junaidi $^{3}$, NourmaPramestie Wulandari ${ }^{4}$, Ratih Ayu \\ Apsari $^{5}$ \\ 1,2,3,4,5 Pendidikan Matematika, Universitas Mataram \\ ${ }^{1}$ Email: ulfa_1@unram.ac.id
}

\begin{abstract}
The aim of this study is to determine the perceptions of high school students about the use of technology-based mathematics learning media. The subjects in this study were 108 high school students. Data collection was carried out using a questionnaire for students' perceptions of technology-based learning media. Data analysis in this study used descriptive statistical analysis with qualitative methods. The results showed that $21 \%$ of students more often used technology to learn mathematics, $63 \%$ of students more often used smartphones to study mathematics, and $40 \%$ of students more often used learning videos to study mathematics.
\end{abstract}

Keywords:Mathematics Learning Media, Technology, Student Perceptions

\begin{abstract}
Abstrak
Tujuan dalam penelitian ini yaitu untuk mengetahui persepsi siswa SMA terhadap penggunaan media pembelajaran matematika berbasis teknologi. Subjek dalam penelitian ini adalah 108 siswa SMA. Pengumpulan data dilakukan dengan menggunakan angket persepsi siswa terhadap media pembelajaran berbasis teknologi. Analisis data dalam penelitian ini menggunakan analisis statistik deskriptif dengan metode kualitatif. Hasil penelitian menunjukkan bahwa $21 \%$ siswa lebih sering memanfaatkan teknologi untuk belajar matematika, 63\% siswa lebih sering menggunakan smartphone untuk belajar matematika, dan $40 \%$ siswa lebih sering menggunakan video pembelajaran untuk belajar matematika.
\end{abstract}

Kata kunci:Media Pembelajaran Matematika, Teknologi, Persepsi Siswa

Cara Menulis Sitasi: Cara Menulis Sitasi: Lu'luilmaknun, U., Salsabila, N.H., Junaidi, Wulandari, N.P., \& Ratih, A. P (2020). Pemanfaatan media pembelajaran matematika berbasis teknologi: Persepsi siswa SMA. Mathematic Education and Aplication Journal, Volume 2, no.1, hal. 1-7

Pembelajaran matematika bagi beberapa siswa masih dirasa sulit, begitu juga untuk siswa SMA. Jika siswa berpandangan negatif terhadap matematika maka materi matematika akan sulit diterima oleh siswa. Mereka yang menganggap matematika sebagai pelajaran yang relatif sulit terhadap matematika umumnya berdampak buruk bagi motivasi belajar matematika sedangkan sikap yang positif terhadap matematika yang terbentuk sejak awal merupakan faktor penting pada kesuksesan belajar matematika (Siregar, 2017: 225). Salah satu cara yang dapat memotivasi siswa dan membantu siswa untuk belajar matematika yaitu menggunakan media pembelajaran. Media pembelajaran yang menarik dan interaktif dapatmempengaruhi cara belajar peserta didik menjadi lebih efisien dan efektif (Adeliyanti, Suharto, \& Hobri, 2018: 123).

Ada berbagai macam jenis media pembelajaran, diantaranya yaitu buku paket, lembar kerja siswa (LKS), alat peraga, game pembelajaran berbasis android, video pembelajaran, power point, dan lain sebagainya. Game pembelajaran berbasis android, video pembelajaran, dan power point adalah 
beberapa contoh media pembelajaran teknologi. Seperti yang kita ketahui bahwa teknologi sudah dimanfaatkan dalam berbagai bidang kehidupan, seperti memanfaatkan teknologi sebagai media pembelajaran.Namun, penggunaan media pembelajaran berbasis teknologi masih jarang digunakan di beberapa sekolah. Menurut Rohendi (2012: 1) bahwa pemanfaatan teknologi dalam pembelajaran di Indonesia masih kurang. Oleh karena itu, guru dianjurkan untuk mencoba menggunakan media pembelajaran berbasis teknologi untuk mengikuti perkembangan zaman.

Beberapa peneliti telah dapat mengembangkan media pembelajaran berbasis teknologi untuk siswa SMA. Penelitian oleh Hendriawan dan Muhammad (2018) yang bertujuan untuk mengembangkan multimedia pembelajaran matematika berbasis android dengan nama JiMath untuk siswa SMA, menghasilkan bahwa JiMath efektif digunakan sebagai multimedia penunjang belajar. Penelitian oleh Bardi dan Jailani (2015) yang bertujuan untuk menghasilkan multimedia berbasis komputer yang layak untuk pembelajaran matematika bagi siswa SMA, menghasilkan bahwa produk multimedia pembelajaran hasil pengembangan termasuk dalam kategori "sangat baik" dan persentase siswa yang mencapai ketuntasan belajar setelah menggunakan multimedia pembelajaran hasil pengembangan termasuk dalam kategori "baik". Dari beberapa penelitian tersebut, guru dapat menggunakan beberapa media pembelajaran berbasis teknologi yang telah dikembangkan.

Dari uraian yang sudah dipaparkan sebelumnya, untuk dapat mengimplementasikan media pembelajaran berbasis teknologi pada siswa SMA, kita perlu mengetahui bagaimana siswa SMA memanfaatkan teknologi dalam kehidupan sehari-sehari. Penelitian ini bertujuan untuk mengetahui persepsi siswa SMA terhadap penggunaan media pembelajaran matematika berbasis teknologi. Penelitian ini juga dapat dijadikan sebagai pelengkap studi pendahuluan untuk penelitian selanjutnya.

\section{METODE}

Jenis penelitian pada penelitian ini adalah penelitian kuantitatif. Subjek penelitian yaitu 108 siswa kelas X dan XI pada salah satu SMA yang ada di kota Mataram, Nusa Tenggara Barat. Teknik pengumpulan data dilakukan menggunakan angket persepsi siswa terhadap media pembelajaran berbasis teknologi. Analisis data dalam penelitian ini menggunakan analisis statistik deskriptif dengan metode kualitatif. Angket mengenai persepsi mereka terhadap penggunaan media pembelajaran berbasis teknologi pada pembelajaran matematika. Dari angket tersebut, data yang dianalisis berfokus padapemanfaatan teknologi pada siswa, perangkat yang sering digunakan oleh siswa untuk belajar matematika, dan jenis pembelajaran berbasis teknologi yang digunakan siswa untuk belajar matematika. 


\section{HASIL DAN PEMBAHASAN}

\section{Pemanfaatan Teknologi pada Siswa SMA}

Hampir semua siswa SMA sudah memanfaatkan teknologi pada kehidupan sehari-hari. Beberapa siswa ada yang memanfaatkan teknologi untuk belajar, bermedia sosial, berbelanja, menonton youtube, bermain game dan lain sebagainya. Pemanfaatan teknologi pada siswa SMA dapat dilihat pada Gambar 1.

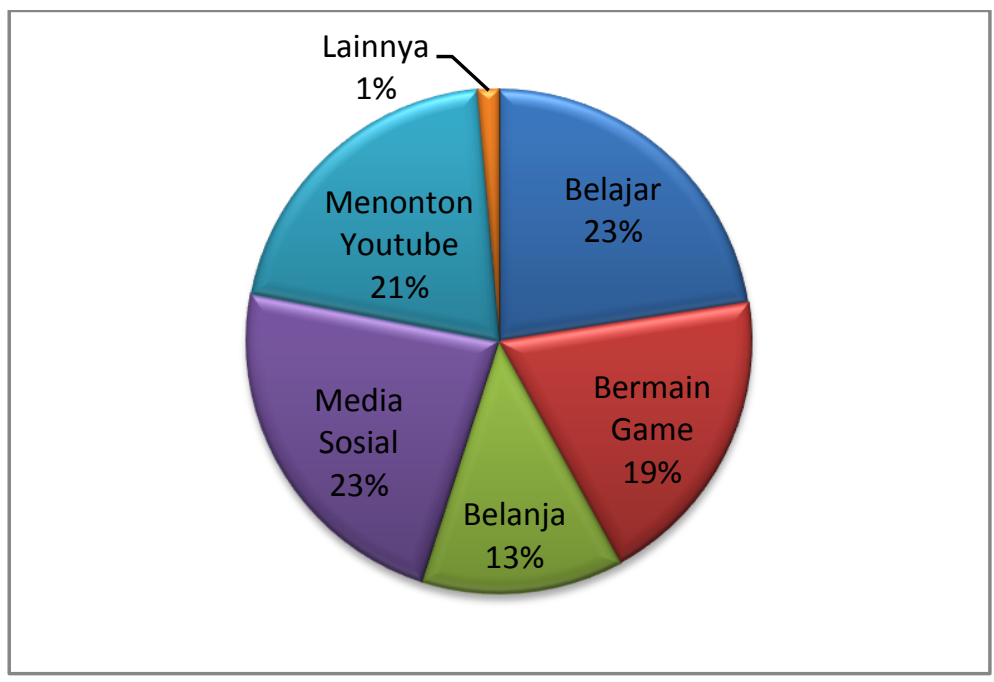

Gambar 1. Pemanfaatan teknologi pada siswa SMA.

Pada Gambar 1, terlihat bahwa ada 23\% siswa SMA memanfaatkan teknologi untuk belajar dan bermedia sosial. Dari data tersebut, banyak siswa SMA yang memanfaatkan teknologi untuk belajar hampir sama dengan banyak siswa SMA yang memanfaatkan teknologi untuk bermedia sosial. Terbukti bahwa sudah ada siswa SMA yang memanfaatkan teknologi untuk belajar. Oleh karena itu, teknologi sudah dapat dimanfaatkan untuk menjadi media pembelajaran di kelas.

Ada 21\% siswa SMA memanfaatkan teknologi untuk menonton Youtube.Ada 19\% siswa SMA yang memanfaatkan teknologi untuk bermain game dan $1 \%$ siswa SMA memanfaatkan teknologi untuk yang lainnya. Beberapa siswa memanfaatkan teknologi untuk menonton Youtube, bermain game, dan lainnya tetapi belum tentu berkaitan dengan pembelajaran. Dari data tersebut, siswa SMA ada yang gemar menonton Youtube dan bermain game. Oleh karena itu, Youtube dan Game dapat dimanfaatkan sebagai media pembelajaran untuk memotivasi siswa.

\section{Perangkat yang Digunakan untuk Belajar Matematika}

Beberapa contoh perangkat yang sering digunakan siswa SMA dalam belajar matematika diantaranya yaitu komputer, laptop, smartphone, tablet, dan lain sebagainya. Sebagian besar siswa SMA sudah memiliki perangkat pribadi. Perangkat yang sering digunakan siswa SMA untuk belajar matematika disajikan pada Gambar 2. 


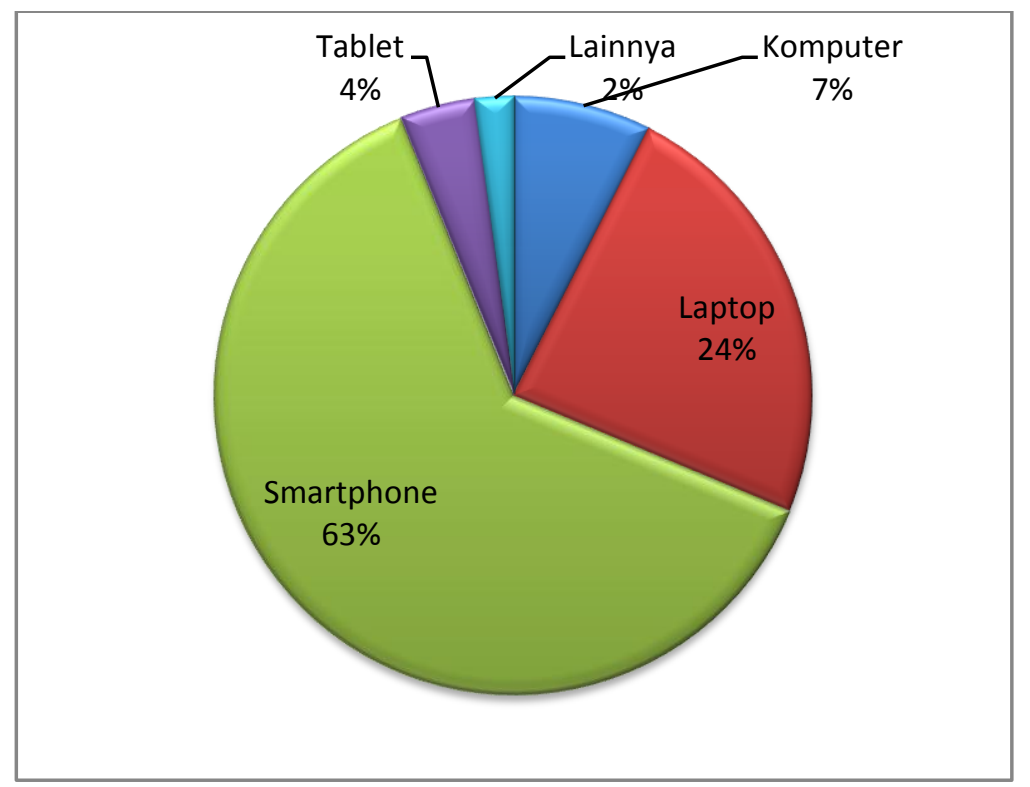

Gambar 2.Perangkat yang sering digunakan siswa SMA untuk belajar matematika.

Pada Gambar 2, terlihat bahwa ada 63\% siswa SMA menggunakan smartphone untuk belajar matematika. Hampir semua siswa SMA sudah memiliki smartphone pribadi. Smartphone adalah perangkat yang paling mudah dibawa kemanapun dan aplikasi pembelajaran yang ditawarkan sangat beragam. Smartphone juga memiliki beberapa fitur yang hampir sama dengan komputer atau laptop, sehingga siswa lebih banyak menggunakan smartphone untuk belajar matematika.

Ada 24\% siswa SMA menggunakan laptop untuk belajar matematika dan ada 7\% siswa SMA menggunakan komputer untuk belajar matematika.Ada 4\% siswa SMA menggunakan tablet untuk belajar matematika dan $1 \%$ siswa SMA menggunakan jenis perangkat lainnya untuk belajar matematika. Data tersebut menunjukkan bahwa lebih banyak siswa SMA yang menggunakan laptop daripada komputer untuk belajar matematika. Hanya beberapa siswa yang menggunakan tablet dan perangkat lainnya untuk belajar matematika.

Menurut penelitianCambridge International, Global Education Cencus terhadap 502 siswa berusia 12-19 tahun yang dirilis pada November 2018, menunjukkan bahwa 67\% siswa menggunakan smartphone dalam pembelajarn di kelas. Sejalan dengan penelitian ini, bahwa lebih banyak siswa menggunakan smartphone untuk belajar.

\section{Jenis Pembelajaran Berbasis Teknologi yang Digunakan untuk Belajar Matematika}

Berbagai macam jenis pembelajaran berbasis teknologi sudah banyak dikembangkan. Beberapa jenis pembelajaran yang sering digunakan siswa SMA dalam belajar matematika adalah pembelajaran online, game pembelajaran, video pembelajaran, power point, dan lain sebagainya. Jenis pembelajaran berbasis teknologi yang sering digunakan siswa SMA untuk belajar matematika disajikan pada Gambar 3 . 


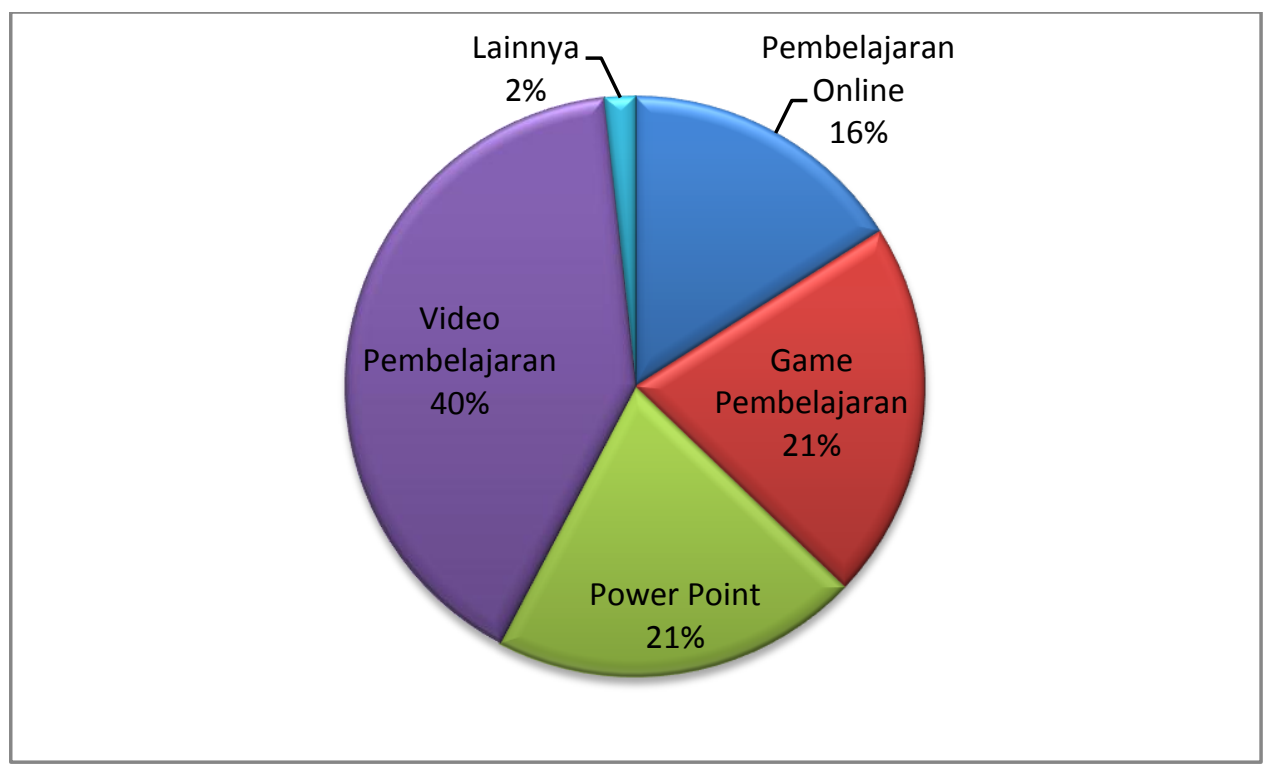

Gambar 3.Jenis pembelajaran berbasis teknologi digunakan siswa SMA untuk belajar matematika.

Pada Gambar 3, terlihat bahwa ada 40\% siswa SMA menggunakan video pembelajaran untuk belajar matematika. Ada beberapa penelitian yang menunjukkan bahwa video pembelajaran matematika dapat berpengaruh positif bagi siswa SMA.Penelitian yang dilakukan oleh Nugroho, Widada, Zamzaili, \& Herawaty (2019), menunjukkan bahwa pembelajaran etnomatematika berbasis Youtube menggunakan Corel Video Studio X10 berpengaruh positif terhadap kemampuan pemahaman konsep siswa. Penelitian oleh Muna, Nizaruddin, dan Murtianto (2017), menunjukkan bahwa prestasi belajar siswa yang menggunakan video pembelajaran matematika berbantuan Macromedia Flash 8 dengan pendekatan kontekstual pada materi program linier kelas XI lebih baik daripada siswa yang tidak menggunakannya. Penelitian oleh Suwarno (2017), menunjukan terdapat saluran Youtube yang menyediakan sumber belajar matematika untuk dipelajari siswa sudah cukup baik dijadikan sumber belajar siswa dan dapat menjadi sumber belajar matematika yang potensial, namun ada beberapa sisi positif serta negatif yang perlu diperhatikan.

Ada $21 \%$ siswa SMA menggunakan game pembelajaran danpowerpoint untuk belajar matematika. Penelitian oleh Casnan, Mahpudin, dan Puadi (2018) mengenai game pembelajaran Geocaching, menunjukkan bahwa media pembelajaran Geocaching dapat meningkatkan motivasi belajar siswa pada pelajaran matematika. Penelitian oleh Febriyanti (2016) menghasilkan bahwa media pembelajaran microsoft power point efektif dalam meningkatkan hasil belajar siswa pada materi pokok bangun ruang dimensi tiga. Dari beberapa penelitian tersebut bahwa game pembelajaran dan powerpoint berpengaruhh positif terhadap motivasi dan hasil belajar siswa SMA.

Ada 16\% siswa SMA menggunakan pembelajaran online untuk belajar matematika dan $2 \%$ siswa SMA menggunakan pembelajaran berbasis teknologi lainnya untuk belajar matematika.Penelitian oleh Anggoro dan Yunianta (2019), menunjukkan bahwa media pembelajaran berbasis website materi 
trigonomnetri dapat efektif digunakan dalam proses pembelajaran. Pembelajaran berbasis website adalah salah satu jenis pembelajaran online yang dapat digunakan dalam pembelajaran matematika.

\section{KESIMPULAN}

Dari hasil penelitian dan pembahasan dapat ditunjukkan bahwa $21 \%$ siswa lebih sering memanfaatkan teknologi untuk belajar matematika, 63\% siswa lebih sering menggunakan smartphone untuk belajar matematika, dan $40 \%$ siswa lebih sering menggunakan video pembelajaran untuk belajar matematika. Saran untuk peneliti selanjutnya yaitu mencari bagaimana pengaruh media pembelajaran matematika berbasis teknologi terhadap pembelajaran matematika pada siswa SMA. Penelitian ini dapat dijadikan referensi untuk penelitian selanjutnya.

\section{DAFTAR PUSTAKA}

Adeliyanti, S., Suharto, \& Hobri. (2018). Pengembangan e-comic matematika berbasis teknologi sebagai suplemen pembelajaran pada aplikasi fungsi kuadrat. Kadikma, 9(1), 123-130.

Anggoro, I. F., \& Yunianta, T. N. H. (2019). Pengembangan media pembelajaran berbasis website materi trigonometri siswa SMA kelas XI. Math Didactic: Jurnal Pendidikan Matematika, 4(2018), 253-260.

Bardi, \& Jailani. (2015). Pengembangan multimedia berbasis komputer untuk pembelajaran matematika bagi siswa SMA. Jurnal Inovasi Teknologi Pendidikan, 2(1), 49-63.

Cambridge Assessment International Education. (2018). Indonesian students among the world's highest users of technology, (https://www.cambridgeinternational.org/news/newsdetails/view/indonesian-students-among-the-worlds-highest-users-of-technology-27-nov2018/), diakses 2 Januari 2020.

Casnan, Mahpudin, A., \& Puadi, E. F. W. (2018). Penerapan permainan interaktif Geocaching untuk meningkatkan motivasi siswa dalam belajar sebagai inovasi baru pembelajaran matematika. UNION: Jurnal Ilmiah Pendidikan Matematika, 6(1), 53-60.

Febriyanti, R. (2016). Penerapan media Microsoft Power Point dalam pembelajaran matematika materi pokok bangun ruang dimensi tiga pada siswa SMA. Seminar Nasional Matematika Dan Pendidikan Matematika UNY 2016, 137-142.

Hendriawan, M. A., \& Muhammad, G. M. (2018). Pengembangan JIMATH sebagai multimedia pembelajaran matematika berbasis android untuk siswa sekolah menengah atas. MaPan: Jurnal Matematika Dan Pembelajaran, 6(1), 274-288.

Muna, H., Nizaruddin, \& Murtianto, Y. H. (2017). Pengembangan video pembelajaran matematika berbantuan macromedia flash 8 dengan pendekatan kontekstual pada materi program linier kelas XI. Aksioma, 8(2), 9-18.

Nugroho, K. U. Z., Widada, W., Zamzaili, \& Herawaty, D. (2019). Pemahaman konsep matematika melalui media Youtube dengan pendekatan etnomatematika. Jurnal Pendidikan Matematika 
Raflesia (JPMR), 04(01), 96-106.

Rohendi, D. (2012). Developing e-learning based on animation content for improving mathematical connection abilities in high school students. International Journal of Computer Science Issues (IJCSI), 9(4), 1-5.

Siregar, N. R. (2017). Persepsi siswa pada pelajaran matematika: studi pendahuluan pada siswa yang menyenangi game. Prosiding Temu Ilmiah X Ikatan Psikologi Perkembangan Indonesia, 224232.

Suwarno, M. (2017). Potensi youtube sebagai sumber belajar matematika. Pi: Mathematics Education Journal, 1(1), 1-7. 